\title{
Introduction of Problem Based learning as an innovative T-L method in Physiology at Dr Shankarrao Chavan Govt Medical College, Nanded
}

\author{
Dr.Mungal Shreechakradhar U. ${ }^{1}$, Dr. Santoshkumar A. Dope ${ }^{2}$, Dr. Sushil P. \\ Dube $^{3}$, Dr. N. D. Somwanshi ${ }^{4}$, Dr. S.S.Karadkhedkar ${ }^{5}$, Dr. M. B. Kulkarni ${ }^{6}$. \\ ${ }^{1}$ Assistant Professor, ${ }^{3}$ Assistant Professor,${ }^{4}$ Professor, ${ }^{5}$ Assistant Professor, ${ }^{6}$ Assistant Professor, \\ Department of Physiology, Dr.Shankarrao Chavan Govt. Medical College, Nanded. Maharashtra, India. \\ 2 Assistant Professor, Department of Anatomy, Government Medical College, Latur. Maharashtra, India.
}

Abstract : Many organizations across the world have adopted Problem Based learning (PBL) as a small group teaching - learning (T-L) tool. PBL inculcates self directed learning in students. If PBL is included in the curriculum of basic sciences like Physiology, it can help students to apply knowledge of Physiology in clinical practice. So this study is undertaken as a pilot project to introduce PBL as an innovative T-L method in curriculum of Physiology at Dr. Shankarrao Chavan Government Medical College, Nanded.

In this study one PBL session was conducted on cardiovascular Physiology in Dept of Physiology at Dr. S.C. Govt. Medical College Nanded, India. An MCQ test was conducted before and after PBL session. Students' perspectives on $P B L$ were studied by taking feedback from the students.

Result: Students commented that PBL made the teaching-learning more interesting. Students opined that $P B L$ enabled them for better understanding of the subject and motivated them for self directed learning and to read more. Students also commented that PBL enabled them to remember the subject better and helped to integrate their knowledge. Most of the students expressed a desire and a need to continue PBL sessions in future also.

Keywords: PBL-Problem based learning, Teaching - Learning (T-L) method, Physiology curriculum

\section{INTRODUCTION}

Teaching learning is a continuously changing process. Over the years, various studies convinced that traditional discipline based curriculum in medical education is dehumanizing and demotivating. It is also convinced that students learn better when actively involved in their learning tasks and basic science would be better understood, remembered and subsequently applied if learned in a clinically relevant format [1]. Nurturing these needs, in recent years, Problem based Learning is being widely used in Medical Education all over the world $[2,3]$.

With the observation of a gap between the qualitative and quantitative advancement in medical education and achievements in the field of health care prompted the Medical Council of India to adopt a need based curriculum for undergraduate medical education in India. "Regulations on Graduate Medical Education, 1997" recommend a teaching approach characterized by maximal efforts to encourage integrated teaching between traditional subject areas using a problem based learning approach and de-emphasize compartmentalization of disciplines so as to achieve both horizontal and vertical integration in different phases[4].

Many organizations across the world have adopted Problem Based learning (PBL) as a small group teaching - learning (T-L) tool. PBL inculcates self directed learning in students .Also it develops problem solving attitude and analytical skills in students. If PBL is included in the curriculum of basic sciences like Physiology, it can help students to apply knowledge of Physiology in clinical practice. Also students will get early orientation of clinical education.

So this study is undertaken as a pilot project to introduce PBL as an innovative T-L method in curriculum of Physiology at Dr. Shankarrao Chavan Government Medical College, Nanded.

\section{AIMS AND OBJECTIVES}

\subsection{Aims}

The aim of this study is to develop self directed learning, problem solving attitude and analytical skills in the students and also to increase competency of forthcoming health professionals.

2.2 Objectives

2.1.1 By the end of six months, students should develop self directed learning.

2.1. 2 By the end of six months, faculties should get sensitized and develop interest to use PBL as 
teaching learning method.

2.1.3 To study perspectives of students and faculties regarding PBL as teaching learning method.

\section{Material And Method}

Present study was carried over a period of four months in the Department of Physiology, Dr. Shankarrao Chavan Government medical College, Nanded. Participants for this study were $\mathrm{I}^{\text {st }}$ MBBS students of 2012 batch of Dr. S. C. Govt. Medical College, Nanded, India. First approval of ethical committee was taken. Students were randomly distributed in 10 groups.

Faculties and students were sensitized for procedure of PBL by an interactive seminar on pattern of PBL. A Problem (Annexure I) based on applied aspect of cardiovascular Physiology was constructed by consensus of all faculties. Specific learning objectives were also set by consensus of all faculties. A MCQ test (Annexure II) was taken to assess students' knowledge on the topic.

A Problem (Annexure I) based on applied aspect of cardiovascular Physiology was posed to groups. In all groups there was one leader, one time keeper, one recorder, one reporter and a teacher as a facilitator. Groups discussed and extracted learning areas for study from the problem. Then student went home and studied different learning areas, they have identified during discussion. After 3-4 days the groups of students sat together and discussed facts they studied about the problem. They analyzed if there was any learning area which still required more study. Again they went home and read about learning areas newly identified and again discussed after 3-4 days. They repeated the procedure till they satisfied about solution of the problem.

The same MCQ test, which was taken before PBL session, was repeated after PBL session to assess the knowledge gained. Feedback was taken from the students by providing pretested and validated questionnaires (Annexure III). Feedback included constructed response with open ended questions and selected responses with Likert scale and overall Global Rating Scale.

\section{Results}

48 students participated and gave the feedback.

Data obtained was analyzed using SPSS 21.00 Version

Paired T Test was applied for comparing pre PBL and post PBL test scores of students

Table 1 Comparison between Pre PBL score and Post PBL score

\begin{tabular}{|l|l|l|l|l|l|}
\hline \multicolumn{6}{|c|}{ Paired $\mathbf{t}$ test analysis for comparison between Pre PBL score and Post PBL score } \\
\hline & Mean & $\mathrm{N}$ & Std. Deviation & Std. Error Mean & P value \\
\hline $\begin{array}{l}\text { Pre PBL } \\
\text { test score }\end{array}$ & 5.1667 & 48 & 0.8337 & 0.1203 & $<0.0001$ \\
\hline Post PBL test score & 8.1875 & 48 & 0.5322 & 0.07682 & \\
\hline
\end{tabular}

( $P$ value $<0.001-$ highly significant)

There is significant difference in scores of students before and after PBL session.

Table 2 Students perspectives on different aspects of PBL

\begin{tabular}{|c|c|c|c|c|c|c|}
\hline & Item & $\begin{array}{l}\text { No. of } \\
\text { students said } \\
\text { Don't agree }\end{array}$ & $\begin{array}{l}\text { No. of } \\
\text { students } \\
\text { said } \\
\text { Somewhat } \\
\text { agree }\end{array}$ & $\begin{array}{l}\text { No. of } \\
\text { students } \\
\text { said } \\
\text { agree }\end{array}$ & $\begin{array}{l}\text { No. of students } \\
\text { said Strongly } \\
\text { agree }\end{array}$ & $\begin{array}{l}\text { No. of } \\
\text { students } \\
\text { said } \\
\text { Very } \\
\text { strongly } \\
\text { agree }\end{array}$ \\
\hline 1 & $\begin{array}{l}\text { In understanding a particular topic PBL } \\
\text { was very useful }\end{array}$ & $5(10.41 \%)$ & $3(6.25 \%)$ & $\begin{array}{l}26 \\
(54.17 \%)\end{array}$ & $12(25 \%)$ & $2(4.17 \%)$ \\
\hline 2 & $\begin{array}{l}\text { In PBL sessions, a valuable exchange of } \\
\text { ideas took place in group discussions }\end{array}$ & $2(4.17 \%)$ & $2(4.17 \%)$ & $\begin{array}{l}20 \\
(41.67 \%) \\
\end{array}$ & $21(43.75 \%)$ & $3(6.25 \%)$ \\
\hline 3 & $\begin{array}{l}\text { By virtue of PBL sessions, clinical } \\
\text { conditions could be better related to basic } \\
\text { mechanisms }\end{array}$ & $4(8.33 \%)$ & $3(6.25 \%)$ & $\begin{array}{l}14 \\
(29.17 \%)\end{array}$ & $23(47.92 \%)$ & $4(8.33 \%)$ \\
\hline 4 & $\begin{array}{l}\text { PBL sessions will help you in preparing } \\
\text { you for the final university examination }\end{array}$ & $6(12.5 \%)$ & $\begin{array}{l}5 \\
(10.42 \%)\end{array}$ & $\begin{array}{l}21 \\
(43.75 \%)\end{array}$ & $14(29.17 \%)$ & $2(4.17 \%)$ \\
\hline 5 & $\begin{array}{l}\text { It is better to replace tutorial classes with } \\
\text { PBL }\end{array}$ & $2(4.17 \%)$ & $2(4.17 \%)$ & $\begin{array}{l}27 \\
(56.25 \%)\end{array}$ & $13(27.08 \%)$ & $4(8.33 \%)$ \\
\hline 6 & $\begin{array}{l}\text { PBL helps to develop self directed } \\
\text { learning }\end{array}$ & $9(18.75 \%)$ & $4(8.33 \%)$ & $\begin{array}{l}16 \\
(33.33 \%) \\
\end{array}$ & $13(27.08 \%)$ & $6(12.5 \%)$ \\
\hline 7 & $\begin{array}{l}\text { PBL helps to develop analytical skills in } \\
\text { students }\end{array}$ & $8(16.67 \%)$ & $\begin{array}{l}5 \\
(10.42 \%) \\
\end{array}$ & $\begin{array}{l}18 \\
(37.5 \%) \\
\end{array}$ & $14(29.17 \%)$ & $3(6.25 \%)$ \\
\hline 8 & $\begin{array}{l}\text { All didactic lectures should be replaced by } \\
\text { PBL }\end{array}$ & $21(43.75 \%)$ & $\begin{array}{l}10 \\
(20.83 \%)\end{array}$ & $12(25 \%)$ & $3(6.25 \%)$ & $2(4.16 \%)$ \\
\hline 9 & $\begin{array}{l}\mathrm{PBL} \text { increases your involvement in } \\
\text { teaching learning process }\end{array}$ & $2(4.16 \%)$ & $2(4.16 \%)$ & $\begin{array}{l}32 \\
(66.67 \%) \\
\end{array}$ & $9(18.75 \%)$ & $3(6.25 \%)$ \\
\hline
\end{tabular}


Eighty three percent participants opined that they better understood the topic with PBL. Ninety two percent of participant opined a valuable exchange of ideas took place in group discussions. Eighty five percent participants opined clinical conditions could be better related to basic mechanisms. Seventy seven percent of participants reported that PBL sessions will help them in preparing you for the final university examination. Huge agreement i.e. $92 \%$ was reported by participants for replacing tutorial classes with PBL. Seventy three percent of participants reported that PBL developed self directed learning and analytical skills in them. Ninety two percent of the participants reported that PBL increased their involvement in teaching learning process. Surprisingly there was disagreement on replacing all lectures by PBL, only thirty five percent of participant thought it is better to replace all lectures by PBL. Response of the participants on Global Rating Scale showed maximum score from 7-9 towards high side. Participants reported no disadvantage of the new method.

In the comments received from students they reported that in PBL students got fair chance to discuss about their each and every queries with peers as well with faculties which made their understanding of the topic better. Some of the students also reported that while explaining a concept to others they found a flaw in their own understanding and it was corrected there and then only. Some of the students opined that PBL can not replace lectures as all the basic mechanism in Physiology can't be covered in PBL. Instead they suggested there should be a short lecture either at the start of the PBL session or as concluding component of PBL session. Some students also pointed out that there is a need of formal training of facilitators for PBL as some of the facilitators were excellent in their job but some facilitators were job dominating group discussions instead of facilitation.

\section{Discussion}

There has been always a question in whether a problem based form of teaching could be conducted in basic science departments. Faculty members have expressed doubts about the wisdom, effectiveness, and educational efficacy of such a format to teaching the sciences basic to medicine [5]

Experiments by medical teachers have shown that it is possible to introduce a problem-based form of learning into a new course in parallel with more traditional modes of teaching, making it successful to some extent for students who are used to a didactic form of curriculum [6]. Our study revealed that posing problems of clinical situation to students make the inquiry driven learning more interesting. Students commented in their feedback that PBL enhanced their understanding of Physiology and motivated them to read more. Students also commented that PBL enabled them to remember the subject better and helped to integrate their knowledge. All these outcomes are may be due to active involvement of students and peer to peer teaching and motivation in teaching learning process in PBL. Most of the students expressed a desire and a need to continue PBL sessions in future also. On contrary they don't want to replace all the lectures by PBL as they think all the basic mechanisms cannot be covered in PBL.

Apparent benefits of PBL include development of self directed learning, problem solving attitude, and analytical skills. PBL forms a crucial part in the initiation of students into medicine.

\section{Conclusion}

In view of excellent rating from students for PBL, it should be continued in the curriculum of Physiology incorporating students' suggestions. An objective analysis of effectiveness of PBL can be made by comparing students' performances with and without PBL.

\section{References}

[1]. Laeora Berkson. Problem based learning: Have the expectations been met? Academic Medicine, Volume 68, Number 10, October Supplement 1993, 579-588.

[2]. Albanese, M. A., and S. Mitchell. Problem-based learning: a review of literature on its outcomes and mplementation issues. Acad. Med. , 68(1)), January 1993, 52-81,.

[3]. Barrows, H. S. Problem-based learning in medicine and beyond: a brief overview. New Dir. Teach. Learn, 68, $1996,3-12$.

[4]. Medical Council of India: Salient features of Regulations on Graduate Medical Education 1997 [http://www.mciindia.org/know/rules/ rules_mbbs.htm]. accessed Oct 08, 2007

[5]. Schmidt HG. Problem based learning: rationale and description. Med Educ, 17, 1983, 11-16.

[6]. 6. Morrison JM, Murray TS. An experiment in problem based learning. Med Educ, 28, 1994 139-145.

\section{ANNEXURE 1}

A 57 year old man presented to the Accident and Emergency Unit of his local district general hospital complaining of $2 \mathrm{~h}$ of central 'crushing' chest pain radiating to the neck and shoulders. This had begun shortly after dinner and was more severe than any pain he had previously experienced. His wife explained that for the last 4 months he had been having episodes of 'indigestion' at work which were only partially relieved by selfadministered antacid preparations. They had first rung their General Practitioner but he had advised them to call for an ambulance urgently. The past medical history included a diagnosis of hypertension 8 years earlier. At the 
time of admission his only relevant drug history was nifedipine $20 \mathrm{mg}$ twice daily. The family history included the sudden death of his father aged 55 years (cause unknown). It was also known that his mother was hypertensive, his elder brother had angina .He was married with two sons and worked as a bus driver. He was a regular smoker (20 per day) and consumed approximately 16 units of alcohol per week. On examination he looked grey and unwell, and was sweating. The blood pressure was $138 / 94 \mathrm{mmHg}$, pulse 96 regular and the jugular venous pressure was not elevated. The apex beat was undisplaced but thrusting in character and the heart sounds were normal. The peripheries were cold to the touch but there was no ankle oedema. The foot pulses on the left were absent and there was a femoral bruit on the left. He was mildly tachypnoeic but the chest was clear on auscultation. Discuss the use of ECG for the diagnosis of underlying disease:

ECG of the affected person is shown in following photograph:

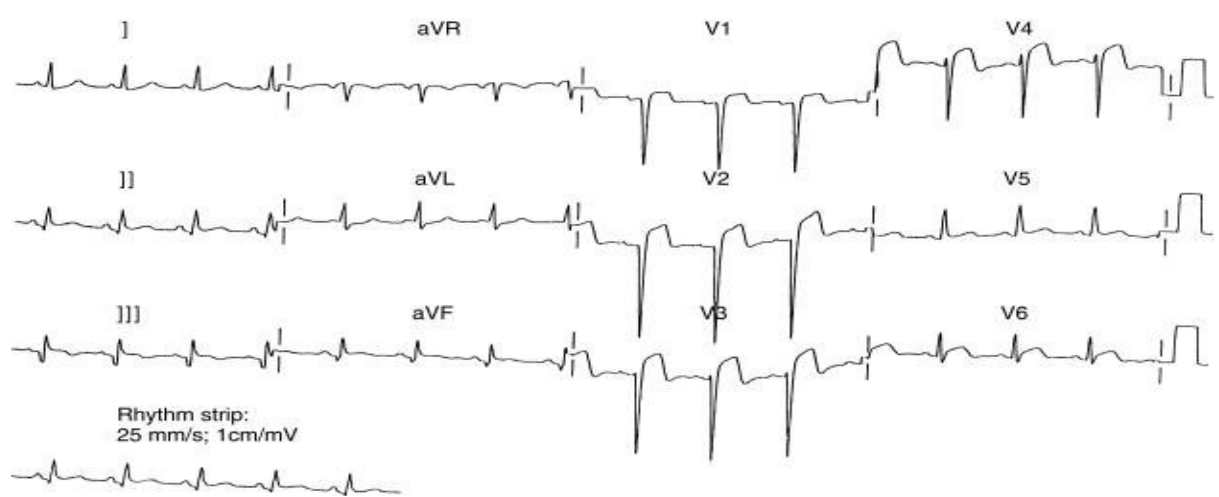

\section{ANNESURE II}

1- In the fundamental rules of the ECG all the following are right EXCEPT:

a) It is a biphasic record of myocardial action potential potential fluctuations.

b) Deflection record occurs only during complete depolarization or repolarization.

c) + ve wave occurs when depolarizing current approaches the +ve terminal electrode of the voltmeter.

d) -ve wave happens when repolarizing current approaches the +ve terminal electrode.

2. Regarding the causes of the ECG waves all the following are correct EXCEPT:

a) $\mathrm{P}$ wave is caused by atrial depolariazation.

b) QRS complex is caused by ventricular depolarization.

c) T wave is caused by ventricular repolarization.

d) U wave by papillary muscle depolarization.

3. The causes of the ECG "intervals":

a) PR by AV nodal conduction.

b) ST by atrial repolarization.

c) QT by ventricular depolarization and ventricular repolarization.

d) All of the above.

\section{In the ECG:}

a) ST segment is part of depolarization \& coincides with plateau.

b) T wave has the same voltage of QRS.

c) QRS \& $T$ wave are in the same direction.

d) QRS \& T wave are in opposite directions.

5. The voltage of the ECG:

a) Is normal summation of QRS complexes in standard limb leads.

b) Is normally $>1.5 \mathrm{mV}$.

c) Is low in individual having body mass index (BMI) 35 .

d) All of the above.

6. Regarding the flow of electrical currents around the heart all the followings are correct EXCEPT:

a) From left to right in the mid portion of the ventricular septum.

b) From the base to the apex during almost depolarization.

c) From the epicardium to the subendocardium during repolarization.

d) From the epicardium to the subendocardium during depolarization.

\section{Axis of the heart is:}

a) Mean instantaneous vector of QRS complexes in vertical plane. 
b) Normally from-30 to +60 .

c) Deviated to left side in full term pregnant woman.

d) Deviated to right side in long slender person (e.g., +80 )

8. The ' $J$ ' point on ECG is
a) End of $Q$ wave and beginning of $R$ wave
b) End of $\mathrm{P}$ wave and beginning of $\mathrm{P}-\mathrm{R}$ interval
c) End of S wave and beginning of ST segment
d) End of PR interval and beginning of R wave

9.

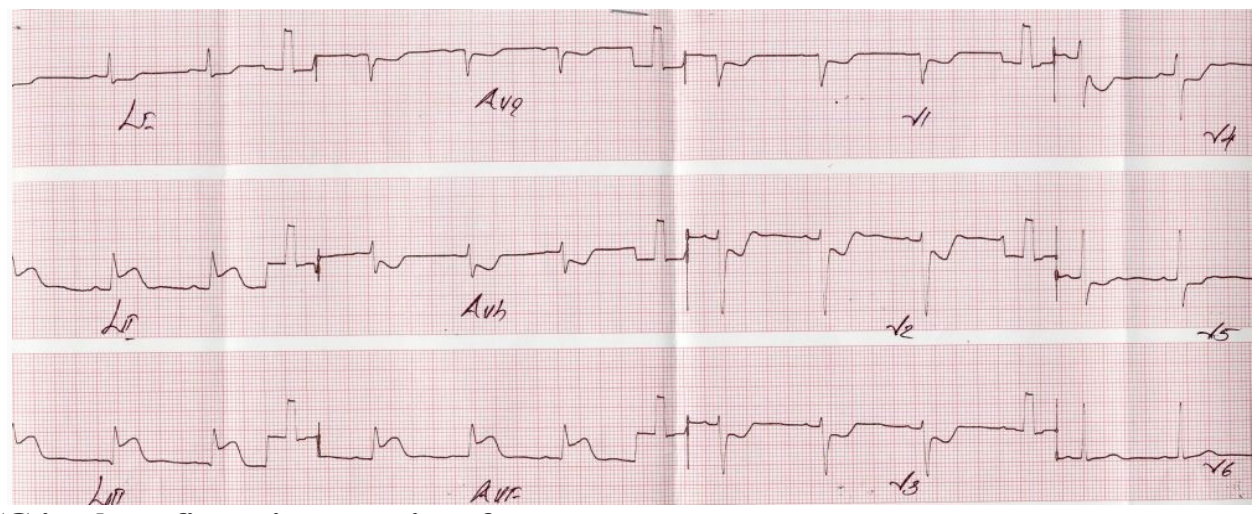

The ECG in above figure is suggestive of:
a) Acute anterior wall myocardial infarction
b) Old inferior wall infarction
c) Hyperacute inferior wall infarction
d) Posterior wall infarction

10 . Right axis deviation is seen in

a) Right bundle branch block

b) Left bundle branch block

c) AV nodal block

d) Block in inter atrial pathway

ANNEXURE III

\begin{tabular}{|c|l|l|l|l|l|l|}
\hline & \multicolumn{1}{|c|}{ Item } & $\begin{array}{l}\text { Don't } \\
\text { agree }\end{array}$ & $\begin{array}{l}\text { Somewhat } \\
\text { agree }\end{array}$ & agree & $\begin{array}{l}\text { Strongly } \\
\text { agree }\end{array}$ & $\begin{array}{l}\text { Very strongly } \\
\text { agree }\end{array}$ \\
\hline 1 & $\begin{array}{l}\text { In understanding a particular topic PBLwas very } \\
\text { useful }\end{array}$ & & & & & \\
\hline 2 & $\begin{array}{l}\text { In PBL sessions, a valuable exchange of ideas took } \\
\text { place in group discussions }\end{array}$ & & & & & \\
\hline 3 & $\begin{array}{l}\text { By virtue of PBL sessions, clinical conditions could } \\
\text { be better related to basic mechanisms }\end{array}$ & & & & & \\
\hline 4 & $\begin{array}{l}\text { PBL sessions will help you in preparing you for the } \\
\text { final university examination }\end{array}$ & & & & & \\
\hline 5 & It is better to replace tutorial classes with PBL & & & & & \\
\hline 6 & PBL helps to develop self directed learning & & & & & \\
\hline 7 & PBL helps to develop analytical skills in students & & & & & \\
\hline 8 & All didactic lectures should be replaced by PBL & & & & & \\
\hline 9 & $\begin{array}{l}\text { PBL increases your involvement in teaching } \\
\text { learning process }\end{array}$ & & & & & \\
\hline
\end{tabular}

$0=$ don't agree, $1=$ Somewhat agree, $2=$ Agree, $3=$ strongly agree, Very strongly agree

Q.1 What aspects of PBL contributed most to your learning?

Q.2 What aspects of PBL should be changed to make it better for you?

Q. 3 Have the skills learned during PBL made a difference in your other academic or social situations? If yes How?

Q.4 General comment on PBL session. 